\title{
Taxonomic investigations of cyanobacterial and algal flora from the Southern Altai, East Kazakhstan
}

\author{
Lenka Caisová $^{1 \mathrm{a}, 2}$, Tomáš Bešta ${ }^{1 \mathrm{~b}}$, Jiří Chlachula ${ }^{3 \mathrm{c}}$, Jiří Komárek Ko $^{1 \mathrm{~d}, 2}$ \\ \& Štěpán Husák ${ }^{2 e}$
}

\begin{abstract}
${ }^{1}$ University of South Bohemia, Faculty of Biological Sciences, Branišovská 31, 37005 České Budějovice, Czech Republic, e-mail: alcaisova@gmail.com, beBobiz@seznam.cz, dkomarek@butbn.cas.cz

${ }^{2}$ Institute of Botany, Academy of Sciences of the Czech Republic, Dukelská 135, 37982 Třeboň, Czech Republic, e-mail: ehusak@butbn.cas.cz ${ }^{3}$ Laboratory for Palaeoecology, Institute of System Studies, T. Bata University Zlín, 68601 Uh. Hradiště, Czech Republic, e-mail: cAltay@seznam.cz
\end{abstract}

\begin{abstract}
The study presents results of pilot investigations (2005-2007) of micro-vegetation biodiversity in marginally explored mountain and forest-steppe areas of southern Altai, East Kazakhstan. On the basis of morphological phenotypes and ecological demands a total of 351 taxa of cyanobacteria and algae were identified in the principal biotopes (rivers and streams, backwaters, irrigation channels, lakes, high-tundra periglacial and barren land settings, snow fields, and pedogenic /soil cover/ environments) of the territorial topographic gradient of ca. 400-3900 m a.s.1. Microbiological records display a remarkable taxonomic variability, including several previously undescribed endemic species of algae adapted to locally specific geoenvironmental conditions. The present results show a major potential for future systematic phycological studies integrated in the complex nature monitoring and management strategy in protected areas of the Altai. The results also demonstrate a limited impact of modern human activity on the quality of local water sources with only minor present ecological risks in balance with the traditional lifestyles of pastoralist communities.
\end{abstract}

Key words: cyanobacteria, algae, taxonomy, microflora, biodiversity, southern Altai, East Kazakhstan

\section{Introduction}

The present state of scientific knowledge on microflora of Kazakhstan is rather limited. Only few articles, concerning local cyanobacteria and algae, have been published to date (e.g., Muzafarov 1965; Ergashev 1974). Although algal and cyanobacterial microflora has been previously studied in Turkmenistan, Uzbekistan, Tajikistan, Kyrgyzstan and the southern Kazakhstan (Obukhova 1952; Vozzhennikova 1953; Kiselev 1955; Muzafarov 1965; Ergashev 1974; Masharipov 1976; Shoyakubov et al. 1976), the eastern part of Kazakhstan still belongs to the least researched microbiologically and largely unknown regions of Central Asia.

The key study area is located in the central part of the southern Altai Mountains, East Kazakhstan, belonging to the Paleoarctic biogeographical zone of southern Siberia, well-known for high numbers of unique and endemic species of flora and fauna (Androsova 1977).
The principal investigations of cyanobacteria and algae were carried out in the territory of the Katon-Karagay National Nature Park $\left(648 \mathrm{~km}^{2}\right)$ and the Lake Markakol Nature Protection Zone $\left(455 \mathrm{~km}^{2}\right)$ as a part of a complex biodiversity mapping of pristine natural areas of East Kazakhstan. Most of the investigated territory (with MAT $+1^{\circ} \mathrm{C}$ ) is covered by semi-arid steppes and foreststeppes in river valleys, and by mixed taiga forests, dark coniferous forests and alpine tundra in the mountains, following the topographic gradient above the crystallinic bedrock.

The discussed data result from systematic pilot studies of freshwater and aerophytic flora carried out in the Kazakh zone of the Altai within the framework of ecological and biotic investigations of the broader Altai region, following the studies of cyanobacterial and algal flora in pristine soils of Gorno Altai, Siberia (Chlachula et al. 2002; Koutný et al. 2003). Since the original species variability of cyanobacteria and algae represents proxy 
indicators of water quality, the assembled database derived from the main biotopes/habitats of the local ecosystems (aquatic, terrestrial, air-related and snow-cover related) was also used to assess quality of the main water systems, particularly of the Bukhtarma River with its tributaries, draining the studied territory.

\section{Material and methods}

\subsection{Material sampling and processing}

Cyanobacterial and algal flora sampling was performed during the summer seasons of 2005-2007. Approximately 225 aquatic samples were collected from the Bukhtarma and Berel Rivers: their main channels, backwaters and stagnant water pools; irrigation channels, bogs, mountain streams, snow-fields and post-glacial mountain lakes (Jazovo, Dzhindagatuy, Markakol), with the latter biotically compared to the continental lacustrine basins of eastern Kazakhstan (Lakes Zaysan and Kopchegay) (Fig. 1). In addition, aerophytic microvegetation was sampled from exposed rock surfaces and modern pedogenic (soil) horizons. Cyanobacterial and algal flora from the present pastures, past-grazed and non-grazed areas were used for a close contextual taxonomic evaluation (Fig. 2).

The collected biotic material was dried, fixed in $1.5 \%$ formaldehyde or kept alive in the Petri dishes with sterile BG11 nutrient medium. Soil samples were placed on agar plots with BG11 nutrient medium in Petri dishes and cultivated under laboratory conditions for 4 weeks. Diatom permanent slides were prepared in compliance with standard procedures (Houk 2003).

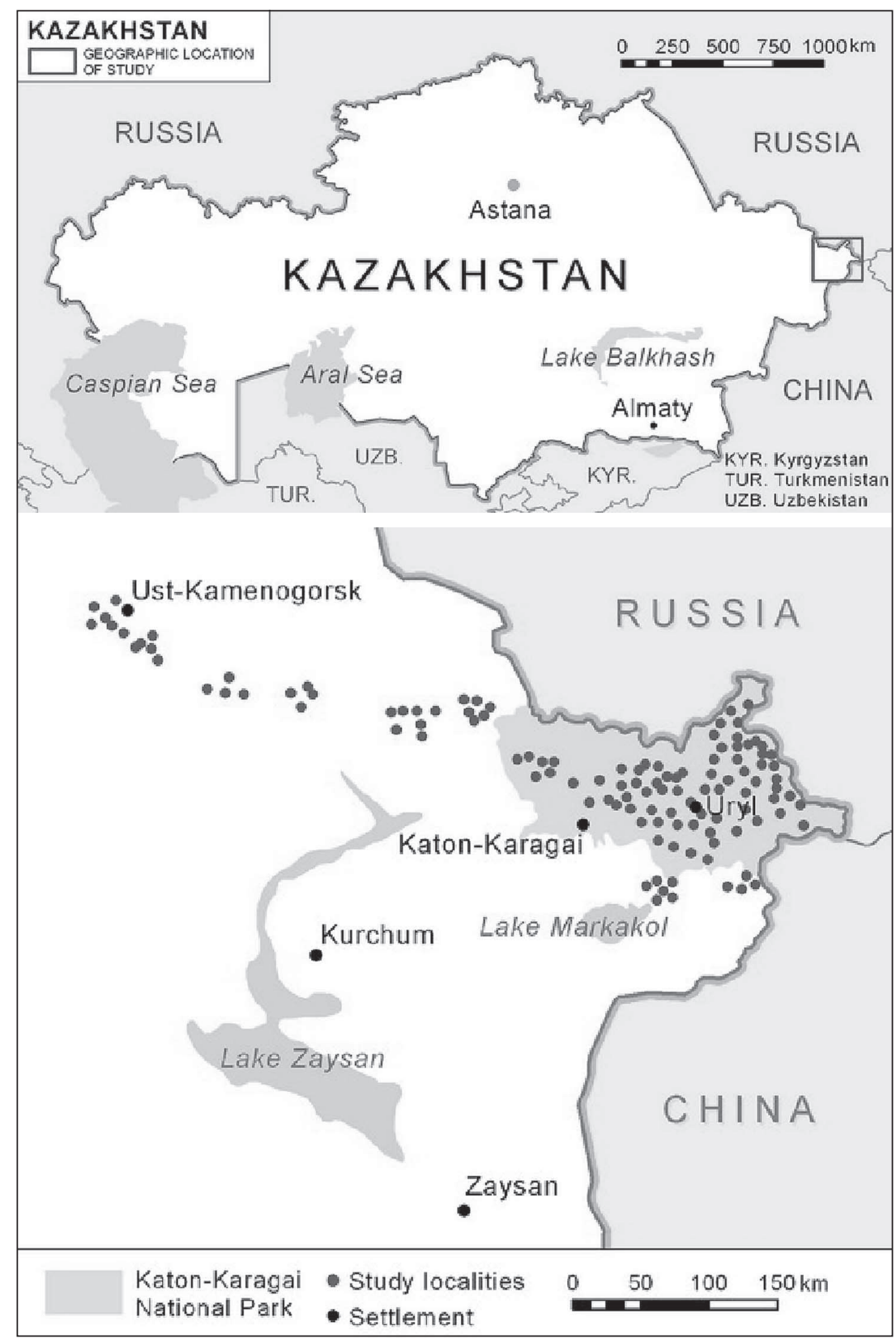

Fig. 1. Location map of the study area, East Kazakhstan, with the marked investigated localities 


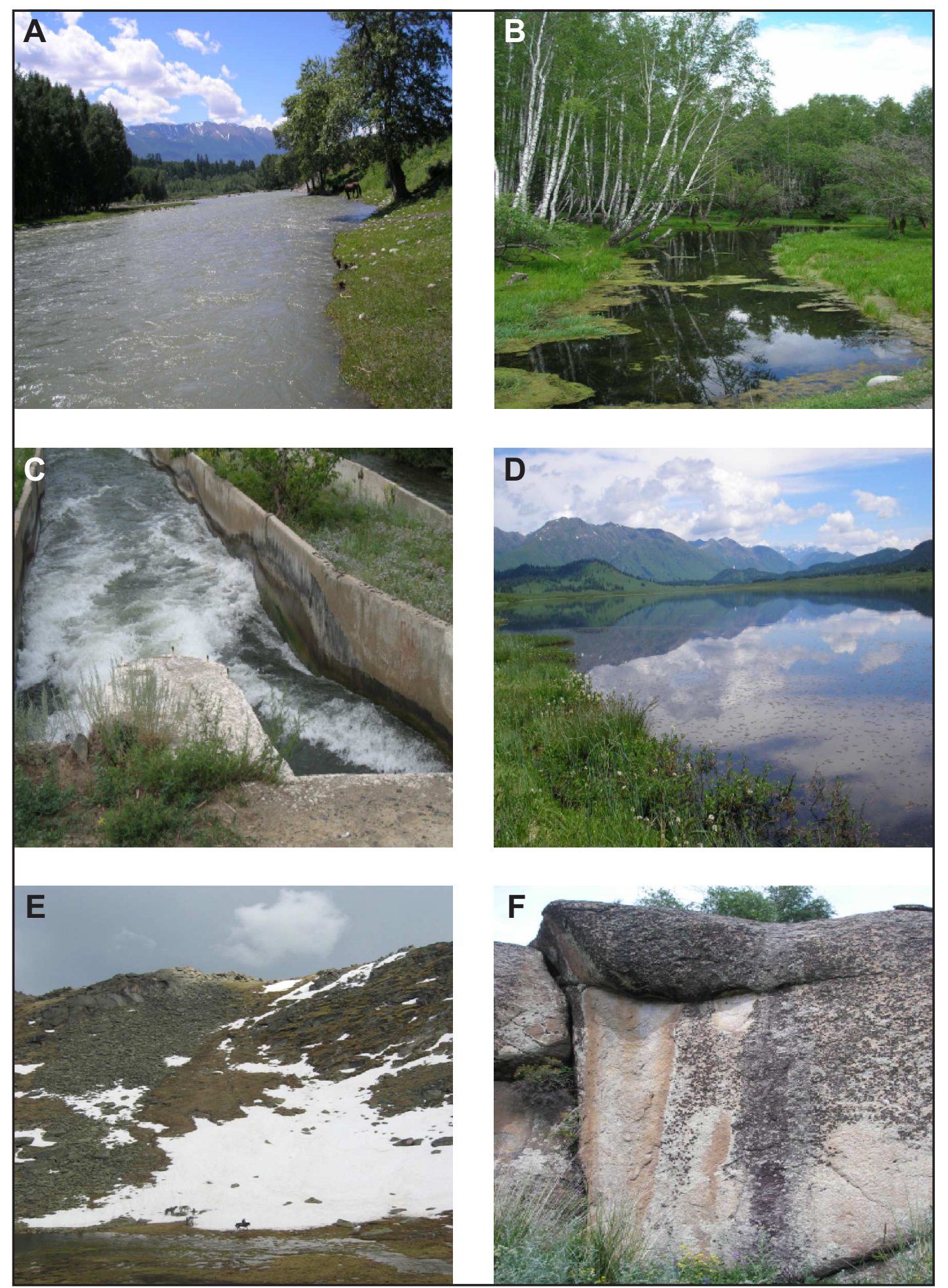

Fig. 2. The investigated Southern Altai biotopes

Explanations: A - Bukhtarma River, B - backwaters, C - irrigation channels (Zaysan Basin), D - Lake Jazovo, E - snow fields and barren lands (alpine Altai settings), $\mathrm{F}$ - aerophytic vegetation of cyanobacteria (black spots)

\subsection{Taxonomic identification}

Taxonomic identification of Conjugatophyceae and Charophyta followed Poljanskiy (1955), Krasnoperova (1970, 1971), Krasavina (1974), Hollerbach \& Krasavina (1975), Rundina (1977); diatoms were determined according to Krammer \& Lange-Bertalot $(1986,1988$, 1991a, 1991b) and Krammer (1997a, 1997b, 2000,
2003). Identification of particular morphotypes is based on the cited literature (Geitler 1932; Elenkin 1936-1949; Starmach 1972; Komárek \& Anagnostidis 1999, 2005; Houk 2003). Although contemporary taxonomic literature was applied, determination of several taxa was uncertain or unfeasible, suggesting existence of some still undescribed endemic microflora taxa, adapted to local, highly specific geo-environmental conditions. 
The taxonomical classification of algae was applied according to Lee (2008).

\section{Results and discussion}

The total number of the currently determined taxa includes: Cyanobacteria (82), Rhodophyta (1), Dinophyta (3), Heterokontophyta: Chrysophyceae (4), Bacillariophyceae (171), Xanthophyta (4), Chlorophyta (87) and Charophyta (3). Identification of some species turned out to be rather problematic. Only $88 \%$ of Bacillariophyceae, $28 \%$ of Cyanophyta and $24 \%$ of Chlorophyta were identified to a specific level. Great numbers of undetermined Cyanophyta (20) and Chlorophyta (15) taxa suggest the presence of new genera or species. The occurrence distribution of particular taxa is summarized in Table 1.

Algal flora was strongly affected by low temperatures of mountain waters, mainly of glacial origin. Therefore, algal species typical for the spring season occurred most frequently in the studied samples. The principal investigated biotopes are represented by rivers and streams, backwaters, irrigation channels, lakes, aerophytic tundra settings (barren lands, snow fields) and pedogenic environments of the present soil cover (Fig. 2).

\subsection{Rivers and Streams}

Both indifferent species and indicator taxa of clean and cold water conditions (Hydrurus foetidus (Vill.) Trev., Ulothrix sp., Microspora sp. and Meridion circulare (Grev.) Ag. predominated in the samples from the fluvial environments (river valleys).

At higher altitudes (above $1700 \mathrm{~m}$ a.s.1.), the algal and cyanobacterial communities were replaced by lichens. Kiselev (1955), Muzafarov (1965) and Ergashev (1974) found similar taxa in the majority of river channels in Turkmenistan, Uzbekistan, Tajikistan, Kyrgyzstan and the southern part of Kazakhstan, apart from the commonly represented taxa of Oedogonium sp., Zygnema sp., Nostoc verrucosum Valch. ex Born. and Flah., in addition to various types of Phormidium sp.

As unusual aspect is the absence of species Prasiola fluviatilis (Sommer.) Aresch. ex Lag., which was commonly recorded in river settings of Uzbekistan, Kyrgyzstan and Tajikistan (Muzafarov 1965). Another surprising fact is an almost complete absence of rhodophytes (except for several specimens of Lemanea fluviatilis (L.) C. Ag. found near Lake Markakol), despite frequent records of Batrachospermum moniliforme Roth, Chantransia chalybea (Roth) Fries and Lemanea fluviatilis from the broader Central Asia and Bangia atropurpurea (Roth)

Table 1. Summarizing table of the cyanobacterial and algal taxa (Southern Altai, East Kazakhstan)

\begin{tabular}{|c|c|}
\hline \multicolumn{2}{|c|}{ Cyanophyta } \\
\hline Total number of taxa & 82 \\
\hline Number of taxa identified to the specific level & $18 \%$ \\
\hline Potential new species or genera & $29 \%$ \\
\hline \multicolumn{2}{|c|}{ Rhodophyta } \\
\hline Determined taxa (1) & Lemanea fluviatilis \\
\hline \multicolumn{2}{|c|}{ Dinophyta } \\
\hline Determined taxa (3) & $\begin{array}{l}\text { Peridinium bipes, Peridinium cinctum, } \\
\text { Woloszynskia } \mathrm{sp} .\end{array}$ \\
\hline \multicolumn{2}{|c|}{ Heterokontophyta: Chrysophyceae } \\
\hline Determined taxa (4) & $\begin{array}{l}\text { Dinobryon sp., Hydrurus foetidus (2), } \\
\text { Synura sp }\end{array}$ \\
\hline \multicolumn{2}{|c|}{ Heterokontophyta: Bacillariophyceae } \\
\hline Total number of taxa & 171 \\
\hline Number of taxa identified to the specific level & $82 \%$ \\
\hline Potential new species or genera & $5 \%$ \\
\hline Taxa typical of Central Asia & $\begin{array}{l}\text { Encyonema persilesiacum var. ata-tau, } \\
\text { Cymbella stuxbergii, Synedra goulardii }\end{array}$ \\
\hline \multicolumn{2}{|c|}{ Xanthophyta } \\
\hline Total number of taxa & $\begin{array}{l}7 \text { (from genera Ophiocytium, } \\
\text { Tribonema, Vaucheria) }\end{array}$ \\
\hline \multicolumn{2}{|c|}{$\begin{array}{l}\text { Tribonema, Vaucheria) } \\
\text { Chlorophyta }\end{array}$} \\
\hline Total number of taxa & 86 \\
\hline Number of taxa identified to the specific level & $19 \%$ \\
\hline Potential new species or genera & $15 \%$ \\
\hline \multicolumn{2}{|c|}{ Charophyta } \\
\hline Determined taxa (3) & $\begin{array}{l}\text { Chara sp., Chara aff. vulgaris } 1 \text { and } \\
\text { Chara } \text { aff. vulgaris } 2\end{array}$ \\
\hline
\end{tabular}


C. Ag. recorded in analogous habitats in Kazakhstan (Muzafarov 1965; Ergashev 1974). This phenomenon might reflect various geo-environmental factors, e.g. changes in $\mathrm{pH}$ or light conditions.

Mono-specific populations of cyanobacteria from Hydrococcaceae and some unidentified species of Tapinothrix Sauv. were attached to exposed surfaces of cobbles in mountain streams. The presence of the genera Chaetophora Schrank, Draparnaldia Bory and Stigeoclonium Kütz. is typical of springs and streams emptying the local Altai mountain lakes. Brown-coloured macroscopic mats of Meridion circulare (Bacillarophyceae) dominated in humid and forested high mountain areas. An unknown Cladophora Kütz. species and a population of Chara vulgaris s.l. were found in smaller mountain streams at lower altitudes (700-1000 m a.s.l.). The above mentioned Cladophora species is specific in its morphology and is not identical with the common Cladophora species from Central Asia (Kiselev 1955; Muzafarov 1965). The occurrence of Chara vulgaris s.l. in rapid streams is rather unexpected due to its tight relation to torrential biotopes (Muzafarov 1965; Krasavina 1974; Hollerbach \& Krasavina 1975).

The collected diatom taxa may be generally regarded as "cosmopolitans" characteristic of standing water biotopes, with the occurrence of some species recorded exclusively in Kazakhstan, e.g. Encyonema persilesiacum var. ata-tau Krammer (Krammer 1997a). Although the total number of the found diatom species did not exceed 36 for rivers and 53 for streams, a high occurrence of the currently undetermined species suggests great microflora variability in the Altai.

\subsection{Backwaters}

The species composition of the Altai backwater and palustrine biotopes is rather unique. Bacillariophyta, Chrysophyta and Chlorophyta were recorded from all sampling locations, most of them with the characteristic spring season appearance. The genera of Phormidium Kütz. ex Gom., Synura Ehren., Fragilaria Lyngb., Meridion Ag., Chaetophora, Draparnaldia, Mougeotia Ag. and Zygnema Ag. dominated in the samples.

The Fragilaria and Meridion species formed typical mats, brown-coloured around margins, while Chaetophora, Draparnaldia and some unidentified and evidently undescribed endemic genera, most probably related to the Chaetophorales group, occurred in river valley oxbow lakes. These genera represented the dominant microvegetation component of this particular Altai biotope.

\subsection{Irrigation channels}

Irrigation channels are considered to be a specific anthropogenic type of biotopes with a distinctive cyanobacterial and algal flora (Muzafarov 1965; Ergashev 1974). Some modern irrigation channels were previously studied in the Almaty region, SE Kazakhstan (Ergashev 1974). Micro-vegetation records from two presently abandoned irrigation channels near the Dzhambul village, the Katon-Karagay region in East Kazakhstan, are included in the presented study.

Cyanobacterial and algal flora formed mats of a pale brown and green colour alongside channels. Some interesting species of Calothrix Ag. ex Born. et Flah., Ammatoidea W. West and G. S. West, Leptolyngbya Anagn. \& Kom., and two types of Phormidium, Chlorogloea microcystoides Geitl. was recorded, as well as an unknown taxon of green filamentous algae, approximately comparable to Stigeoclonium without subsidiary branches.

In contrast, Ergashev (1974) distinguished Hydrocoleus brebissonii Kütz., Lyngbya aestuarii (Mert.) Lieb. ex Gom., Microcoleus chthonoplastes (Mert.) Zanar. ex Gom., Plectonema terebrans Born. and Flah., Phormidium molle (Kütz.) Gom., Ph. uncinatum Gom. ex Gom. (cyanobacteria) and Chantransia chalybea, Cladophora glomerata Pilg., Stigeoclonium subuligerum Kütz. from similar biotopes. The Trentepohlia jolithus (Lin.) Wallr., previously reported from a special wooden apparatus (chigir) in irrigation channels in the Almaty region (Ergashev 1974), was not recorded in the investigated area of East Kazakhstan.

The number of gathered diatom species was the lowest (29) from the surveyed southern Altai biotopes. An interesting finding is the unexpected presence of Cymbella helmckei Krammer, until now observed only in Lake Balaton, Hungary (Krammer 2002), and two unknown Pinnularia Ehren. taxa (Pinnularia sp.1 and sp.2) from stream biotopes.

\subsection{Lakes}

The algal species composition observed in the Altai lakes is rather unique and is worth studying in detail. Most of the investigated freshwater lakes (Kopchegay, Dzhindagatuy, Markakol and Zaysan) have some general environmental similarities to the better-investigated saline/brakish Lake Balchash in central Kazakhstan (a large water extent with a stony and sandy lake bottom and littoral vegetation).

Green macroscopic algal taxa-Oedogonium Link, Zygnema, Mougeotia, Cladophora and a group of Charophyta have been mostly documented in large Kazakh lakes (Muzafarov 1965; Krasavina 1974; Hollerbach \& Krasavina 1975; Rundina 1977). During our research only populations of Chara vulgaris s.l. were found. In contrast, Krasavina (1974), Hollerbach \& Krasavina (1975) described the presence of numerous species of Charophytes (Ch. intermedia A. Br., Ch. tomentosa Linn., Ch. schaffneri, Ch. foetida A. Br., Ch. altaica A. Br. emend. Hollerb. or Ch. aspera Willd., Nitella tenuissima (Desv.) Kütz., N. hyalina (De Cand.) 
C. Ag., Nitellopsis obtusa (Desv.) J. Groves and the Tollypela nidifica population) from various regions of Kazakhstan.

The total number of the found diatom taxa (115) and the overall species diversity were much higher in the lake ecosystems than for the rest of the mapped Altai biotopes. The number of unidentified taxa (7) did not reach their absolute and proportional quantity as in the local biotopes of streams and rivers (11 out of 70 taxa). Algal flora of the two closely investigated lakes varies considerably within the general species composition described above, but also between each other. Glacial water sources distinguished the lakes from other studied lacustrine basins. The geo-biological substrate and the presence of macrophytes are the other most differentiating factors. The Jazovo Lake (N 49³3'28.1"'; E 86 18'9.9"; $1659 \mathrm{~m}$ a.s.l.) is a shallow, peaty lake with a sandy bottom located in a mountain valley. The macrophytic species Comarum palustre L., Menyanthes trifolia L. and Warnstorfia exannulata (Schimp. in B.S.G.) Loeske dominate in the littoral zone. The bottom of the lake is covered by vegetation of Chara vulgaris s. 1. Major components of mats attached to macrophytes include Bulbochaete sp., Oedogonium sp., Nostoc linckia (Roth) Born., Tolypothrix sp., Aulosira sp., Chaetosphaeridium sp., Dichothrix sp., Tetraspora sp., Tetrastrum sp., Aulacoseira valida (Grun.) Krammer, Diatoma cf. mesodon (Ehrenb.) Kütz., Epithemia cf. adnata (Kütz.) Bréb., Gomphonema acuminatum Ehrenb., Gomphonema truncatum Ehrenb., Meridion circulare and Pinnularia borealis Ehrenb.

„The Mountain lake" (N 49 $11^{\prime} 02^{\prime \prime}$; E 86 $38^{\prime} 11^{\prime \prime}$; $2528 \mathrm{~m}$ a.s.l.) is a small, shallow lake with a perennial filling source of glacial water, originating in ice-fields on the plateaus of the Southern Altai Range (ca. 4000 $m$ a.s.1.). An unknown species from the genus Stigeoclonium grew predominantly on the shale bedrock. Draparnaldia sp., Tetraspora sp. and cyanobacteria Phormidium retzii (Ag.) Gom. ex Gom., Tolypothrix sp., Tapinothrix sp., Stichosiphon cf. sansibaricus (Hieron.) Dr. and Daily, Hassallia sp., Komvophoron sp., Chamaesiphon cf. incrustans Grun. in Rabenh., Microchaete cf. uberrima N. Carter and Merismopedia glauca (Ehren.) Kütz. were dominant on stones in inflow and outflow settings. Woloszynskia sp., Peridinium bipes F. Stein (Dinophyta) and Cosmarium cf. tetraophtalmum Bréb. ex Ralfs (Conjugatophyceae) were repeatedly identified in plankton.

\subsection{Aerophytic biotopes (barren soils, snow fields)}

Large populations of Stigonema minutum Hassall ex Born. et Flah., Stigonema sp. and Chlorogloea sp. were documented on surfaces of large stones near the village of Arshaty, the upper Bukhtarma river valley (N 49 $17^{\prime} 53^{\prime \prime}$; E 86 33'9,4"; 1201 m a.s.1.). Local cyanobacteria commonly form black, spot-like colonies. Symplocastrum sp. and Eucapsis sp. populations were recorded, isolated from the barren tundra soils. Persisting snow fields situated at altitudes above $2000 \mathrm{~m}$ a.s.l. display in places a reddish colouration, caused by the presence of Chlamydomonas nivalis (Bauer) Wille.

\subsection{Soil biotopes}

The diversity of the main soil types distributed in the broader Altai region reflects the geomorphic and geological context of the specific biotopes with chernozemic, luvisolic, brunisolic, gleysolic and regosolic soil types, corresponding to (parkland-)steppe, seasonally water-saturated steppe, boreal taiga forest, coniferous forest and alpine tundra, respectively (Chlachula 2007). According to studies from other areas, the influence of grazing/pasture on soil micro-vegetation is evident (e.g. Evans \& Johansen 1999; Johansen \& Shubert 2001; Johansen et al. 2001; Türk \& Gärtner 2001). Nevertheless, no clear difference was recorded within the investigated territory in the species composition between the cultivated samples originating from the intensively and extensively grazed areas of East Kazakhstan. The present results are consistent with the conclusions of the research focused on soil microflora in Tajikistan (Melnikova 1956). Additional systematic data should define in detail the particular microflora composition range within the specific soil types.

\section{Summary and conclusions}

The first results of the microflora (cyanobacteria and algae) studies from unexplored mountain areas of the southern Altai and the adjacent forest-steppe and steppe regions of East Kazakhstan display a remarkable taxonomic variability reflecting the unique diversity of local natural environments. Several newly recorded and so far undescribed (or unknown) taxa of algae show a major potential for future systematic studies. The current results also indicate a limited impact of a direct as well as indirect human activity on the local environments (water sources) and minor ecological risks due to the present exploitation of natural resources, both reflecting the traditional historical lifestyles (pastoralism and forestry) practiced by the local Kazakh communities. Only a minor part of the recorded algal species is indifferent to water pollution and is common in clean running as well as stagnant waters. A marginal frequency of the recorded algal taxa is characteristic of anthropogenically polluted waters, thus suggesting an overall pristine and clear regional environment. The present results have been incorporated in the complex biodiversity and ecology management studies of the protected natural areas of the Altai-Sayan Eco-region the Katon Karagay Nature Park in particular. 
Although the present pilot microbiological study was strictly based on morphological determination according to the standard and regionally specific floras, the unique biodiversity of the investigated territory of central Eurasia is rather evident in respect to the overall number of the unclassified endemic micro-vegetation taxa. Future taxonomic investigations, comprising additional contextual ecological and molecular biological data, will further provide a better understanding of the documented cyanobacterial and algal diversity and functioning of the present Altai ecosystems.

Acknowledgements. The biodiversity studies (2005-2007) in the Altai region (the Gorno Altai Republic, East Kazakhstan) were supported by the Ministry of Environment of the Czech Republic (RP/6/2005).

\section{References}

AndRosova E. Y. 1977. Nekotorye redkie i interesnye vidy vodorosley iz rybovodnykh prudov Novosibirskoy oblasti i Altayskogo kraya. Novosti Sist. Nizs. Rast. 14: 3-8.

Chlachula J. 2007. Biodiversity protection of Southern Altai in the context of environmental transformations and socio-economic development. In: J. Chlachula \& A. M. Gazaliev (eds.). Modern approaches to biodiversity protection in the context of steady development achievement of Republic Kazakhstan, pp. 6-15. International Science Conference Papers, Ust-Kamenogorsk.

Chlachula J., Koutný M. \& RŮŽıcka, J. 2002. Climate change and pristine environments of Southern Siberia. Biodegradation 89: 1-4.

Elenkin A. A. 1936-1949. Monografia algarum cyanophycearum aquidulcium et terrestrium in finibus URSS inventarum. Pars spec. (1-2). 1908 pp., Izdavatelstvo AN SSR, Moskva-Leningrad.

Ergashev A. E. 1974. Algoflora iskusstvennykh vodoemov srednej Azii. 250 pp., Akademia nauk Uzbekskoy SSR, Otdel mikobiologii, Izdatelstvo "FAN" Uzbekskoy SSR, Tashkent.

Evans R. D. \& JohAnSEn J. R. 1999. Microbiotic crusts and ecosystem processes. Critical Rev. Plant Sci. 18: 183225.

GeITLER L. 1932. Cyanophyceae. In: Rabenhorst's Kryptog.Fl. 1196 pp. Akad. Verlags. Leipzig.

Hollerbach M. M. \& Krasavina L. K. 1975. O novykh semeistvakh Nitellaceae i Nitellopsidaceae (Charophyta). Novosti Sist. Nizs. Rast. 12:105-110.

Houk V. 2003. Atlas of freshwater centric diatoms with a brief key and descriptions - Part 1 Melosiraceae, Orthoseiraceae, Paraliaceae and Aulacoseiraceae. Czech. Phycol. 1: 1-27.

Johansen J. R. \& Shubert L. E. 2001. Algae in soils. Nova Hedwigia Beih. 123: 297-306.

Johansen J. R., Britton Ch., Rosati T. C., Xuesong L., Clair L. L., Webb B. L., Kennedy A. J. \& Yanko K. S. 2001. Microbiotic crust of the Mojave Desert: factors influencing distribution and abundance. Nova Hedwigia Beih. 123: 341-371.

Kiselev I. A. 1955. Novye i redkie predstaviteli presnovodnych vodoroslej iz Zapadno-kazachstanskoj oblasti. Bot. Mater. Otd. Spor. Rast. Bot. Inst. Komarova 10: 36-38.
Komárek J. \& Anagnostidis K. 1999. Cyanoprocaryota - 1. Teil: Chroococcales. In: H. Ettl, J. Gerloff, H. Heynig \& D. Mollenhauer (eds.). Süßwasserflora von Mitteleuropa, Band 19/1, pp. 548. Gustav Fischer Verlag.

KomÁrek J. \& AnAgnostidis K. 2005. Cyanoprokaryota - 2. Teil/ 2nd Part: Oscillatoriales. In: B. BüdEL, L. Krienitz, G. Gärtner \& M. Schagerl (eds.). Süsswasserflora von Mitteleuropa, Band 19/2, pp. 759. Elsevier/Spektrum, Heidelberg.

KoutnÝ M., RŮŽıcKa J. \& Chlachula J. 2003. Screening for phenol-degrading bacteria in the pristine soils of south Siberia, Appl. Soil Ecology. 23: 79-83.

Krammer K. 1997a. Die Cymbelloiden Diatomeen. Eine Monagraphie der weltweit bekannten Taxa. Teil 1. Allgemeines und Encyonema part. Bibliotheca Diatomologica Band 36. 382 pp. J. Cramer, Stuttgart.

Krammer K. 1997b. Die Cymbelloiden Diatomeen. Eine Monographie der weltweit bekannten Taxa. Teil 2. Encyonema part., Encyonopsis und Cymbellopsis. Bibliotheca Diatomologica Band 37. 469 pp. J. Cramer, Stuttgart.

KrAmMER K. 2000. Diatoms of Europe. Diatoms of European inland waters and comparable habitats. Vol. 1. The genus Pinnularia. 703 pp. A. R. G. Gantner Verlag K. G, Ruggel.

KrAmmer K. 2002. Diatoms of Europe. Diatoms of the European inland waters and comparable habitats. Vol. 3 . Cymbella. 514 pp. A. R. G. Gantner Verlag K.G, Ruggell.

Krammer K. 2003. Diatoms of Europe. Diatoms of the European inland waters and comparable habitats. Vol. 4. Cymbopleura, Delicata, Navicymbulla, Gomphocymbellopsis, Afrocymbella. 530 pp. A. R. G. Gantner Verlag K. G, Ruggell.

KRAMMER K. \& Lange-Bertalot H. 1986. Bacillariophyceae (Naviculaceae). In: H. Ettl, J. Gerloff, H. Heinig \& D. Mollenhauer (eds.). Süsswasserflora von Mitteleuropa. Band 2/1, pp. 876. Gustav Fisher Verlag, Stuttgart.

Krammer K. \& Lange-Bertalot H. 1988. Bacillariophyceae (Bacillariaceae, Epithemiaceae, Surireallaceae). In: H. Ettl, J. Gerloff, H. Heinig \& D. Mollenhauer (eds.). Süsswasserflora von Mitteleuropa, Band 2/2, pp. 596. Gustav Fisher Verlag, Stuttgart. 
Krammer K. \& Lange-Bertalot H. 1991a. Bacillariophyceae (Centrales, Fragilariaceae, Eunotiaceae). In: H. Ettl, J. Gerloff, H. Heinig \& D. Mollenhauer (eds.). Süsswasserflora von Mitteleuropa, Band 2/3, pp. 576. Gustav Fisher Verlag, Stuttgart.

Krammer K. \& Lange-Bertalot H. 1991b. Bacillariophyceae (Achnanteaceae, Kritische Ergänzungen zu Navicula (Lineolateae) und Gomphonema Gesamtliteraturverzeichnis). In: H. Ettl, J. Gerloff, H. Heinig \& D. Mollenhauer (eds.). Süsswasserflora von Mitteleuropa, Band 2/4, pp. 437. Gustav Fisher Verlag, Stuttgart.

Krasnoperova L. A. 1970. Novye, redkie i interesnye dla SSSR zignemovye vodorosli. I. Zygnema bohemicum Czurda, i Mougeotia drouetii Transeau. Novosti Sist. Nizs. Rast. 7: 63-67.

Krasnoperova L. A. 1971. Novye, redkie i interesnye dlja SSSR zignemovye vodorosli. II. Spirogyra dentireticulata Jao, S. punctulata Jao, S. sinensis Li. Novosti Sist. Nizs. Rast. 8: 79-84.

Krasavina L. K. 1974. Charophyta iz chetvertichnykh otlozhenij Bashkirii. Novosti Sist. Nizs. Rast. 11: 8595.

LeE R. E. 2008. Phycology. 547 pp. Cambridge University Press, New York.

MASHARIPOv P. M. 1976. Dinamika chislennosti pochvennykh vodoroslei v otdelnykh bogarnykh rajonakh Uzbekistana. In: T. T. TAubajev (ed.). Algoflora i Mikoflora Srednej Azii, pp. 193-198. Akad. Nauk Uzbekskoy SSR, Tashkent.

Melnikova V. V. 1956. Novye vidy i formy vodorosley, obnaruzhennyje v pochvakh Tadzhikskoy SSR. Bot.
Mater. Otd. Spor. Rast. Bot. Inst. Komarova. 11: 6471.

MuZafarov A. M. 1965. Flora Vodoroslej vodoemov srednej Azii. 567 pp. Nauka Uzbekskoy SSR, Tashkent.

Oвukhova V. M. 1952. K flore desmidievykh vodoroslej Taldy-Kurganskoy oblasti Kazachskoj SSR. Bot. Mater. Otd. Spor. Rast. Bot. Inst. Komarova. 8: 52-61.

PolJANSKIY V. I. 1955. Novye dlja flory SSSR vidy roda Spirogyra Link. Bot. Mater. Otd. Spor. Rast. Bot. Inst. Komarova. 10: 125-134.

Rundina L. A. 1977. Novye, redkie i interesnye dlja SSSR zignemovye vodorosli. III. Predstaviteli rodov Zygnema, Zygnemopsis i Mougeotia iz Kazakhstana. Novosti Sist. Nizh. Rast. 14: 46-63.

Starmach K. 1972. Chlorophyta III. Zielenice nitkowate: Ulothrichales, Ulvales, Prasiolales, Sphaeropleales, Cladophorales, Chaetophorales, Trentepohliales, Siphonales, Dichotomosiphonales. Flora Słodkowodna Polski, 10, 750 pp. PWN, Warszawa-Kraków.

Shoyakubov R. S., Vasigov T. V. \& Rasulov A. A. 1976. Algoflora ochistnykh sooruzheniy Tashkentskoy Oblasti (Akhangaranskoe ochistnoe sooruzhenie). In: T. T. Taubajev (ed.). Algoflora i Mikoflora Srednej Azii, pp. 220-227. Akad. Nauk Uzbekskoy SSR, Tashkent.

Türk R. \& GÄrTnER G. 2001. Biological soil crusts of the subalpine, alpine, and nival Areas in the Alps. Ecol. Stud. 150: 67-73.

VozZHENNIKova T. F. 1953. Novye predstaviteli vodorosley iz gornykh vodotokov Tadzhikistana. Bot. Mater. Otd. Spor. Rast. Bot. Inst. Komarova. 9: 73-75. 
Appendix. List of identified cyanobacterial and algal taxa

\section{Cyanophyta}

Amatoidea sp., Anabaena cf. catenula Born. et Flah., Anabaena sp. 1, Aphanocapsa sp., Aphanothece sp. 1, Aphanothece sp. 2, Aulosira sp., Calothrix sp. 1, Calothrix sp. 2, Calothrix sp. 3, Clastidium sp., Cylindrospermum sp., Dichothrix sp., Eucapsis sp., Fischerella sp., Gloeocapsa sp., Godlewskia sp., Hassallia sp., Heteroleibleinia sp., Hormoscilla pringsheimii Anagn. et Kom., Hydrococcaceae gen.et.sp.dir., Chamaesiphon cf. incrustans Grun. in Rabenh., Chlorogloea microcystoides Geitl., Chlorogloea sp. 1, Chlorogloea sp. 2, Chroococcidiopsis sp., Komvophoron sp. 1, Komvophoron sp. 2, Leptolyngbya cf. foveolarum (Rabenh. ex Gom.) Anagn. et Kom., Leptolyngbya sp. 1, Leptolyngbya sp. 2, Leptolyngbya sp. 3, Leptolyngbya sp. 4, Lyngbya sp. 1, Lyngbya sp. 2, Lyngbya sp. 3, Lyngbya sp. 4, Lyngbya sp. 5, Merismopedia glauca (Ehren.) Kütz., Microchaete cf. uberrima N. Carter, Microchaete sp., Microcoleus sp., Nodularia willei Gard., Nodularia sp., Nostoc commune Vauch. ex Born. et Flah., Nostoc cf. linckia (Roth) Born., Nostoc linckia (Roth) Born., Nostoc sp. 1, Nostoc sp. 2, Nostoc sp. 3, Nostoc sp. 4, Oscillatoria sp., Phormidium aff. autumnale (C. Ag.) Gom., Phormidium ambiguum Gom., Phormidium autumnale (C. Ag.) Gom., Phormidium cf. californicum Dr., Phormidium paulsenianum Boye-Petersen, Phormidium retzii typ 1 (Ag.) Gom. ex Gom., Phormidium retzii typ 2 (Ag.) Gom. ex Gom., Phormidium sp. 1, Phormidium sp. 2, Phormidium sp. 3, Phormidium sp. 4, Pseudanabaena galeata Böch., Spirulina cf. subsalsa Oerst. ex Gom., Spirulina sp., Stigonema informe Kütz. ex Born. et Flah., Stigonema cf. minutum Hassall ex Born. et Flah., Stigonema sp., Stichosiphon cf. sansibaricus (Hieron.) Dr. \& Daily, Symplocastrum sp., Tapinothrix sp. 1, Tapinothrix sp. 2, Tapinothrix sp. 3, Tolypothrix sp. 2, Tolypothrix sp. 1, Tolypothrix sp. 2, Tolypothrix sp. 3, Tolypothrix sp. 4, Tolypothrix sp. 5, Trichormus sp., Xenococcus sp.

Rhodophyta

Lemanea fluviatilis (L.) C. Ag.

Dinophyta

Peridinium bipes F. Stein, Peridinium cinctum (O.F. Müll.) Ehren., Woloszynskia sp.

Heterokontophyta: Chrysophyceae

Dinobryon sp., Hydrurus foetidus (Vill.) Trev., Synura sp. 1, Synura sp. 2

Heterokontophyta: Bacillariophyceae

Achnantheiopsis delicatula (Kütz.) Lange-Bert., Adlafia minuscula var. minuscula (Grun.) Lange-Bert., Achnanthes laevis var. laevis Østrup, Achnanthes lapidosa var. lapidosa Krasske, Achnanthidium biasolettianum aff. var. thienemannii (Hust.) Round et Bukht., Achnanthidium minutissimum var. jackii (Rabenh.) Czarn., Achnanthidium minutissimum var. minutissimum (Kütz.) Czarn., Achnanthidium sp. 1, Amphora cf. inariensis Krammer, Amphora cf. libyca Ehrenb., Amphora montana Krasske, Amphora ovalis (Kütz.) Kütz., Amphora pediculus (Kütz.) Grun., Aulacoseira alpigena (Grun.) Krammer, Aulacoseira cf. canadensis (Hust.) Simonsen, Aulacoseira valida (Grun.) Krammer, Brachysira procera Lange-Bert. et G. Moser, Brachysira styriaca (Grun.) R. Ross, Caloneis sp. 1, Cavinula pseudoscutiformis (Hust.) D.G. Mann et A.J. Stickle, Cavinula cocconeiformis (Greg. ex Greville) D.G. Mann et A.J. Stickle, Cocconeis pediculus Kütz., Cocconeis placentula Ehrenb., Cocconeis placentula var. lineata (Ehrenb.) P. Cleve, Cyclotella bodanica var. aff. lemanica (O. Müller) Bachman, Cyclotella ocellata Pant., Cyclotella radiosa (Grun.) Lemm., Cymatopleura solea (Bréb.) W. Smith, Cymbella affinis Kütz., Cymbella cymbiformis Ag., Cymbella helmckei Krammer, Cymbella lacustris (Ag.) Cleve, Cymbella lanceolata var. lanceolata (Ag.) Ag., Cymbella sp. 1, Cymbella stuxbergii (Cleve) Cleve, Cymbella tumida (Bréb.) Van Heurek, Cymbopleura cuspidata (Kütz.) Krammer, Cymbopleura lapponica (Grun.) Krammer, Cymbopleura naviculiformis (Auersw.) Krammer, Diatoma mesodon (Ehrenb.) Kütz., Diatoma sp. 1, Diatoma tenuis Ag., Diploneis sp. 1, Dydimosphaenia geminata (Lyngb.) M. Schmidt, Encyonema cf. lange-bertalotii Krammer, Encyonema minutum (Hilse) D.G. Mann, Encyonema persilesiacum var. ata-tau Krammer, Encyonema silesiacum (Bleisch) D.G. Mann, Encyonopsis microcephala (Grun.) Krammer, Epithemia adnata (Kütz.) Bréb., Epithemia cf. adnata (Kütz.) Bréb., Epithemia sp., Epithemiaceae sp. 1, Eunotia bilunaris (Ehrenb.) Mills, Eunotia implicata Nörpel et al., Eunotia minor (Kütz.) Grun., Eunotia muscicola var. tridentula Nörpel et Lange-Bert., Eunotia sp. 1, Eunotia sp. 2, Fallacia monoculata (Hust.) D.G. Mann, Fragilaria arcus (Ehrenb.) Cleve, Fragilaria arcus var. recta Cleve, Fragilaria capucina var. amphicephala (Grun.) Lange-Bert., Fragilaria capucina var. distans (Grun.) Boye-Petersen, Fragilaria capucina var. gracilis (̌̌strup) Hust., Fragilaria capucina Dezmaziéres, Fragilaria cf. capucina Dezmaziéres, Fragilaria cf. virescens (Ralfs) D.M. Williams et Round, Fragilaria sp. 1, Fragilaria sp. 2, Fragilaria tenera (W. Sm.) Lange-Bert., Fragilaria vaucheriae (Kütz.) Petersen, Gomphoneis olivacea (Hornem.) Dawson ex Ross et Sims, Gomphoneis sp., Gomphonema acuminatum Ehrenb., Gomphonema angustatum (Kütz.) Rabenh., Gomphonema angustum C. Ag., Gomphonema cf. pumilum (Grun.) Reichardt et Lange-Bert., Gomphonema clavatum Ehrenb., Gomphonema micropus Kütz., Gomphonema parvulum var. exilissimum Grun., Gomphonema parvulum var. parvulum f. saprophilum Lange-Bert. et Reichardt, Gomphonema sarcophagus Greg., Gomphonema sp. 1, Gomphonema truncatum Ehrenb., Gomphonema ventricosum Greg., Gyrosigma attenuatum (Kütz.) Rabenh., Hantzschia amphioxys (Ehrenb.) Grun., Hippodonta capitata (Ehrenb.) Lange-Bert., Metzeltin et Witkowski, Luticola mutica var. mutica (Kütz.) D.G. Mann, Melosira varians Ag., Meridion circulare (Grev.) Ag., Navicula broetzii Lange-Bert. et Reichardt, Navicula capitatoradiata Germain, Navicula cf. stankovicii Hust., Navicula constans Hust., Navicula cryptocephala Kütz., Navicula cryptotenella Lange-Bert., Navicula explanata Hust., Navicula germainii Wallace, Navicula lanceolata (Ag.) Ehrenb., Navicula pseudolanceolata Lange-Bert., Navicula radiosa Kütz., Navicula reichardtiana Lange-Bert., Navicula rhynchocephala Kütz., Navicula sp. 1, Navicula sp. 2, Navicula veneta Kütz., Neidium ampliatum (Ehrenb.) Krammer, Neidium bisculatum 
var. subampliatum Krammer, Nitzschia acicularis (Kütz.) W. Sm., Nitzschia aff. perminuta (Grun.) Perag., Nitzschia amphibia Grun., Nitzschia angustata Grun., Nitzschia angustiforaminata Lange-Bert., Nitzschia cf. agnita Hust., Nitzschia cf. capitelata Hust., Nitzschia cf. communis Rabenh., Nitzschia cf. gracilis Hantzsch, Nitzschia dissipata var. dissipata (Kütz.) Grun., Nitzschia dissipata var. media (Hantzsch) Grun., Nitzschia fonticola Grun., Nitzschia frustulum var. frustulum (Kütz.) Grun., Nitzschia gessneri Hust., Nitzschia heufleriana Grun., Nitzschia linearis var. linearis (Ag.) W. Sm., Nitzschia linearis var. subtilis (Grun.) Hust., Nitzschia palea (Kütz.) W. Smith, Nitzschia palea f. major Rabenh., Nitzschia palea var. minuta Bleisch, Nitzschia pura Hust., Nitzschia recta Hantzsch, Nitzschia sinuata var. delongei (Grun.) Lange-Bert., Nitzschia sp. 1, Nitzschia sublinearis Hust., Nitzschia vitrea Norman, Pinnularia biceps var. biceps Greg., Pinnularia borealis Ehrenb., Pinnularia cf. viridiformis Krammer, Pinnularia pseudacuminata Metzeltin et Krammer, Pinnularia sp. 1, Pinnularia sp. 2, Pinnularia sp. 3, Pinnularia subcapitata Greg., Planothidium frequentissimum (Lange-Bert.) Round et Bukht., Psammothidium cf. bioretii (Germain) Bukht. et Round, Psammothidium cf. chlidanos (M. H. Hohn et Hellerman) Lange-Bert., Psammothidium cf. rossii (Hust.) Bukht. et Round, Psammothidium subatomoides (Hust.) Bukht. et Round, Pseudostaurosira brevistriata (Grun.) D. M. Williams et Round, Reimeria sinuata (Greg.) Kociolek \& Stoermer, Rhoicosphaenia abbreviata (Ag.) LangeBert., Sellaphora pupula var. mutata (Krasske) Poulin, Sellaphora pupula var. pupula (Kütz.) Mereschk., Sellaphora seminulum (Grun.) D. G. Mann, Stauroneis anceps Ehrenb., Stauroneis cf. gracilis Ehrenb., Stauroneis smithii Grun., Stauroneis sp. 1, Staurosira construens f. construens Ehrenb., Staurosirella leptostauron (Ehrenb.) D. M. Williams et Round, Staurosirella pinnata var. pinata (Ehrenb.) D. M. Williams et Round, Stephanodiscus cf. neoastrea Hík. et B. Hickel, Stephanodiscus sp., Surrirella minuta F. Meister, Synedra goulardii Bréb. ex Cleve et Grun., Synedra ulna (Nitzsch) Ehrenb., Tabellaria floculosa (Roth) Kütz., Tabellaria sp.1, Tetracyclus glans (Ehrenb.) Mills, Ulnaria acus (Kütz.) Aboal

\section{Xanthophyta}

Ophiocytium sp., Tribonema sp. 1, Tribonema sp. 2, Tribonema sp. 3, Tribonema sp. 4, Vaucheria sp. 1, Vaucheria sp. 2 Chlorophyta

Ankistrodesmus spiralis (W.B. Turn.) Lemm., Ankistrodesmus sp. 1, Ankistrodesmus sp. 2, Aphanochaete sp., Apiocystis sp., Bulbochaete sp., Haematococcus cf. pluvialis Flotow em. Wille, Chaetophora sp. 1, Chaetophora sp. 2, Chaetopsphaeridium sp., Chlamydomonas nivalis (Bauer) Wille, Chlorella vulgaris Beij., Chlorella $\mathrm{cf}$. vulgaris Beij., Chlorella sp. 1, Chlorella sp. 2, Chlorella sp. 3, Cladophora sp. 1, Cladophora sp. 2, Cladophora sp. 3, Cladophora sp. 4, Cladophora sp. 5, Closterium sp. 1, Closterium sp. 2, Coelastrum microporum Näg. in A.Braun, Cosmarium cf. botrytis Menegh. ex Ralfs, Cosmarium moniliferum (Bory) Ehrenb. ex Ralfs, Cosmarium cf. reniforme (Ralfs) W. Arch., Cosmarium cf. tetraophthalmum Bréb. ex Ralfs, Cosmarium sp. 1, Cosmarium sp. 2, Cosmarium sp. 3, Desmococcus sp., Desmodesmus sp. 2, Desmodesmus sp. 3, Dictyosphaerium sp. 2, Draparnaldia cf. acuta (C. Ag.) Kütz., Draparnaldia cf. glomerata (Vauch.) C. Ag., Draparnaldia sp., Ecdysichlamys sp., Euastrum sp. 1, Euastrum sp. 2, Microspora sp. 1, Microspora sp. 2, Microspora sp. 3, Microspora sp. 4, Microspora sp. 5, Microthamnion cf. strictissimum Rabenh., Monoraphidium obtusum (Korsh.) Kom.-Legn., Mougeotia sp. 1, Mougeotia sp. 2, Mougeotia sp. 3, Oeogonium sp. 1, Oeogonium sp. 2, Podohedra sp. Pseudococcomyxa sp., Scenedesmus acutus var. acutus Meyen, Scenedesmus quadricauda (Turp) Bréb. in Bréb. et Godey, Scenedesmus sp. 1, Scenedesmus sp. 2, Scenedesmus sp. 3, Spirogyra sp. 1, Spirogyra sp. 2, Spirotaenia sp., Staurastrum cf. aciculiferum (G.S. West) O.F. Andersson, Staurastrum cf. eurycerum H.L. Skuja, Staurastrum cf. lunatum Ralfs, Staurastrum sp., Stigeoclonium sp. 1, Stigeoclonium sp. 2, Stigeoclonium sp. 3, Stigeoclonium sp. 4, Stichococcus sp. 1, Stichococcus sp. 2, Tetraspora cf. gelatinosa (Vauch.) Desv., Tetraspora sp. 1, Tetraspora sp. 2, Tetraspora sp. 3, Tetrastrum sp., Ulothrix cf. zonata (Weber \& Mohr) Kütz., Ulothrix sp., Zygnema sp., green heterofilamentous alga 1 , green heterofilamentous alga 2, green heterofilamentous alga 3 , green coccoid alga 1 , green coccoid alga 2, green sarcinoid alga

\section{Charophyta}

Chara sp., Chara vulgaris s.l. 1 L., Chara vulgaris s.1. 2 L. 